\title{
Low temperature structural studies of zinc substituted copper ferrite using synchrotron X-ray powder diffraction
}

\author{
W. Nowicki ${ }^{1, *}$, J. Darul $^{1}$, A. M. T. Bell ${ }^{2}$ \\ ${ }^{1}$ Department of Materials Chemistry, Faculty of Chemistry, Adam Mickiewicz University \\ Poznań, Poland \\ ${ }^{2}$ Hasylab at Desy, Notkestrasse 85, 22607 Hamburg, Germany \\ *Contact author; e-mail: waldek@amu.edu.pl
}

Keywords: powder diffraction, copper-zinc ferrite, cubic to tetragonal transition

\begin{abstract}
Two samples of the spinel ferrite system $\mathrm{Cu}_{1-\mathrm{x}} \mathrm{Zn}_{\mathrm{x}} \mathrm{Fe}_{2} \mathrm{O}_{4}$ with $\mathrm{x}=0.0$ and $\mathrm{x}=0.1$ were synthesised by a combustion method. The effect of zinc ion substitution for copper on low temperature structural properties of $\mathrm{CuFe}_{2} \mathrm{O}_{4}$ ferrite is reported. Synchrotron X-ray measurements have been performed in the temperature range $300 \mathrm{~K}-15 \mathrm{~K}$. It was found that for $\mathrm{Cu}_{0.9} \mathrm{Zn}_{0.1} \mathrm{Fe}_{2} \mathrm{O}_{4}$, the sample begins to transform from cubic to tetragonal at about $250 \mathrm{~K}$, with the coexistence of both phases down to $15 \mathrm{~K}$. No phase transition was observed in the $\mathrm{CuFe}_{2} \mathrm{O}_{4}$ spinel below room temperature.
\end{abstract}

\section{Introduction}

Spinel ferrites, which have vast application from microwave to radio frequencies is of great importance from both fundamental and applied research points of view [1-5]. The spinel structure is based on a cubic close-packed array of oxide ions (32e), with $1 / 2$ of the octahedral sites (16d) and $1 / 4$ of tetrahedral sites (8a) occupied by cations. The general chemical formula is $\mathrm{AB}_{2} \mathrm{O}_{4}$, and there are two ideal structures with different cation ordering schemes: $(\mathrm{A})_{8 \mathrm{a}}\left[\mathrm{B}_{2}\right]_{16 \mathrm{~d}} \mathrm{O}_{4}$ (normal spinel) and $(\mathrm{B})_{8 \mathrm{a}}[\mathrm{AB}]_{16 \mathrm{~d}} \mathrm{O}_{4}$ (inverse spinel). Copper ferrite crystallizes in a tetragonal $(\mathrm{T})$ or cubic $(\mathrm{C})$ symmetry depending on the cation distribution among interstitial sites of spinel structure. The T-phase is an inverse spinel, with the cation distribution that can be presented by the formula: $(\mathrm{Fe})[\mathrm{CuFe}] \mathrm{O}_{4}$. The $\mathrm{Cu}^{2+}$ ions occur copper only octahedral B-sites and this causes the tetragonal distortion due to the cooperative Jahn-Teller effect [6-7]. The Jahn-Teller distortion in cooper ferrite has established that the critical number of octahedral site $\mathrm{Cu}^{2+}$ ions per formula unit for a cooperative distortion to tetragonal symmetry at room temperature is 0.8 [7]. One way to reduce the Jahn-Teller effect, could be the addition of other 3d-cations to the tetragonal $\mathrm{CuFe}_{2} \mathrm{O}_{4}$ lattice [3,7]. Since the zinc ion has a stronger tetrahedral site preference than $\mathrm{Fe}^{3+}$ in the normal spinel $\mathrm{Zn}\left[\mathrm{Fe}_{2}\right] \mathrm{O}_{4}$, we may assume it also does so in $\mathrm{Zn}^{2+}$ doped copper ferrite. In this work, the structural change with decreasing temperature below ambient condition polycrystalline $\mathrm{Cu}_{0.9} \mathrm{Zn}_{0.1} \mathrm{Fe}_{2} \mathrm{O}_{4}$ compound has been compared with that of undoped copper ferrite. 


\section{Experimental details}

Powder samples having nominal composition $\mathrm{CuFe}_{2} \mathrm{O}_{4}$ and $\mathrm{Cu}_{0.9} \mathrm{Zn}_{0.1} \mathrm{Fe}_{2} \mathrm{O}_{4}$ were prepared by a combustion method using citrate-nitrate precursors. The stoichiometric quantities of starting materials, viz., $\mathrm{Cu}\left(\mathrm{NO}_{3}\right)_{2} \cdot 6 \mathrm{H}_{2} \mathrm{O}, \mathrm{Fe}\left(\mathrm{NO}_{3}\right)_{3} \cdot 9 \mathrm{H}_{2} \mathrm{O}, \mathrm{Zn}\left(\mathrm{NO}_{3}\right)_{2} \cdot 4 \mathrm{H}_{2} \mathrm{O}$ and $\mathrm{C}_{6} \mathrm{H}_{8} \mathrm{O}_{7} \cdot 6 \mathrm{H}_{2} \mathrm{O}$ (Merck), were dissolved in distilled water. The mixed citrate-nitrate solution was heated at $120^{\circ} \mathrm{C}$ with continuous stirring. After evaporation of excess of water a highly viscous gel was obtained. Ultimately, the particles were sintered at different temperatures $\left(300,600,900^{\circ} \mathrm{C}\right)$ for five hours and slow cooled down to room temperature. The investigations on the temperature phase transition, using high-resolution powder diffractometer, equipped with Hecryostat and Image Plate OBI detector were carried out at the Desy/Hasylab at the B2 beamline [8-9]. The wavelength applied during measurements, determined by calibration using NIST silicon standard, was $0.49342(1) \AA$. The polycrystalline samples placed in glass capillaries of diameter $0.3 \mathrm{~mm}$ were cooled within a temperature range from $300 \mathrm{~K}$ to $15 \mathrm{~K}$. Refinement of the diffraction data, collected as a function 2-theta were performed using the FullProf [10] and UnitCell [11-12] programs. The program WinPLOTR-2006 (version 0.5 April 2009) was used for the powder diffraction graphic representation [13].

\section{Results and discussion}

Figure 1 displays the RT XRD patterns of the as-prepared samples $\mathrm{CuFe}_{2} \mathrm{O}_{4}$, (A) and $\mathrm{Cu}_{0.9} \mathrm{Zn}_{0.1} \mathrm{Fe}_{2} \mathrm{O}_{4}$, (B). The results of indexing XRD patterns has shown that the nominal composition structures with different concentrations are single phase with no additional lines corresponding to any other phase. Tetragonal structure is obtained only for copper ferrite and all of the peaks are indexed with space group $I 4_{1}$ amd in the standard data (JCPDS no. 340425). In our communication we use the face-centred $\left(F 4_{1} / d d m\right)$ unit cell, with the eight $\mathrm{CuFe}_{2} \mathrm{O}_{4}$ content, as in the spinel $(\mathrm{Fd} 3 \mathrm{~m})$ unit cell, allows us to demonstrate the degree of tetragonal distortion of the crystal lattice.

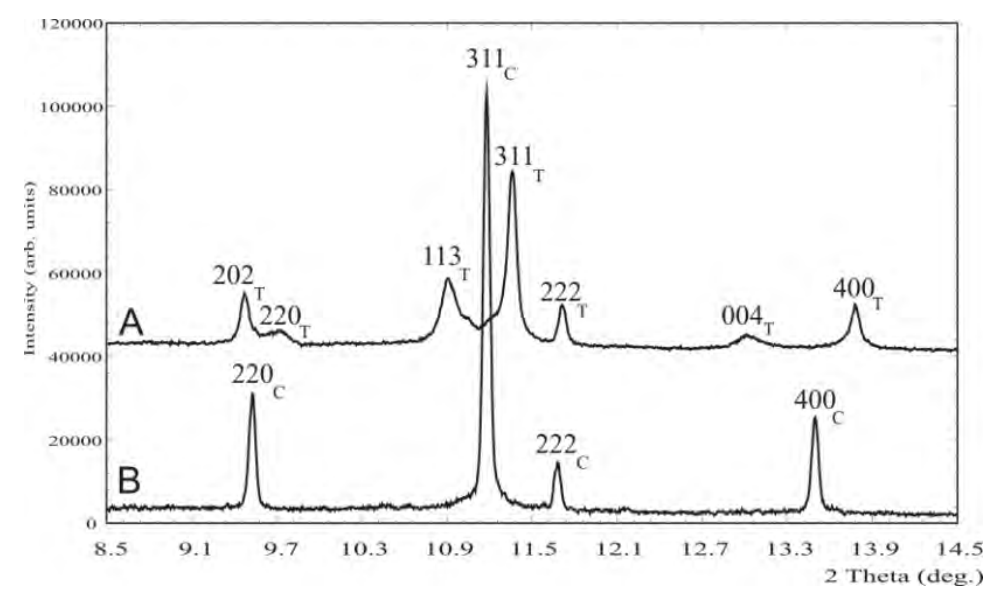

Figure 1. X-ray powder diffraction patterns for $\mathrm{A}$ : $\mathrm{CuFe}_{2} \mathrm{O}_{4}$ (indexing for the tetragonal $\mathrm{F} 4_{1} / \mathrm{ddm}$ space group) and $\mathbf{B}: \mathrm{Cu}_{0.9} \mathrm{Zn}_{0.1} \mathrm{Fe}_{2} \mathrm{O}_{4}$ (indexing for the cubic $\mathrm{Fd} 3 \mathrm{~m}$ space group) at room temperature. 
The second compound $\left(\mathrm{Cu}_{0.9} \mathrm{Zn}_{0.1} \mathrm{Fe}_{2} \mathrm{O}_{4}\right)$, crystallizes in the cubic space group $\mathrm{Fd} 3 \mathrm{~m}$. The structure refinement by the Rietveld method was carried out to determine the cation distribution over tetrahedral and octahedral spinel sites at the room temperature (figure 2). The distribution of cations in $\mathrm{Cu}_{0.9} \mathrm{Zn}_{0.1} \mathrm{Fe}_{2} \mathrm{O}_{4}$ can be expressed as $\left(\mathrm{Cu}_{0.071} \mathrm{Zn}_{0.125} \mathrm{Fe}_{0.804}\right)_{\mathrm{Tet}}\left[\mathrm{Cu}_{0.804} \mathrm{Fe}_{1.196}\right]_{\mathrm{Oct}} \mathrm{O}_{4}$ and shows a critical number of copper ions in the octahedral spinel sublattice for the tetragonal symmetry in copper ferrospinel. Substitution with zinc ions clearly restrains Jahn-Teller effect, owing to the reduction of $\mathrm{Cu}^{2+} / \mathrm{Fe}^{3+}$ ratio in octahedral sites in $\mathrm{CuFe}_{2} \mathrm{O}_{4}$. The unit cell volume is found to increase with addition of zinc in copper ferrite (table 1$)$. This is due to the fact that the ionic radius of $\mathrm{Zn}^{2+}(0.83 \AA)$ is greater than that of $\mathrm{Cu}^{2+}(0.70 \AA)[14]$.

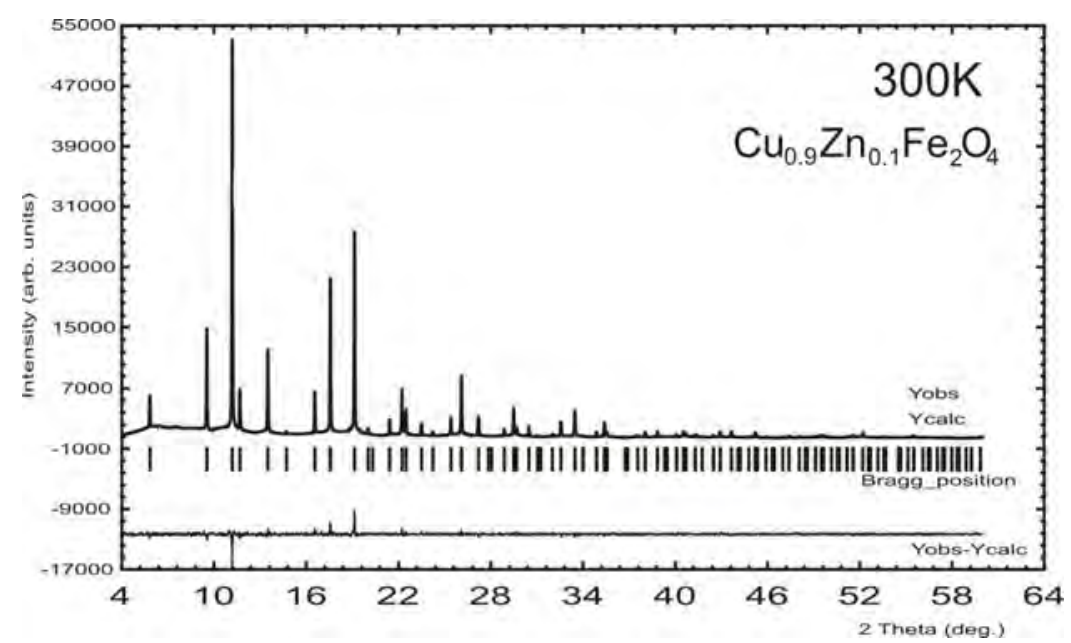

Figure 2. Observed, calculated and difference profiles from the Rietveld analysis of $X$-ray powder diffraction data of the sample $\mathrm{Cu}_{0.9} \mathrm{Zn}_{0.1} \mathrm{Fe}_{2} \mathrm{O}_{4}$, at the room temperature.

Table 1. Lattice parameters and volume for samples with tetragonal and cubic unit cell at the room temperature. $a^{*}$ and $V^{*}$ - value converted to $F 4_{1} d d m$ space group.

\begin{tabular}{|c|c|c|c|c|}
\hline Sample & $c(\AA)$ & $a(\AA)$ & $c / a$ & $V\left(\AA^{3}\right)$ \\
\hline $\mathrm{CuFe}_{2} \mathrm{O}_{4}$ & $8.7047(8)$ & $8.2307(3)^{*}$ & 1.057 & $589.69(0.11)^{*}$ \\
\hline $\mathrm{Cu}_{0.9} \mathrm{Zn}_{0.1} \mathrm{Fe}_{2} \mathrm{O}_{4}$ & - & $8.3943(1)$ & 1.000 & $591.498(0.012)$ \\
\hline
\end{tabular}

The structure of the copper ferrite can be changed via decreasing the copper concentration, or alternatively, by temperature treatments. Annealing can modify the cationic distribution in spinel lattice $-\mathrm{Cu}^{2+}$ ions from octahedral sites migrate to the tetragonal positions. This phenomenon transforms the tetragonally distorted $\mathrm{CuFe}_{2} \mathrm{O}_{4}$ structure into a cubic lattice in the temperature range from $\sim 360^{\circ} \mathrm{C}$ to $\sim 420^{\circ} \mathrm{C}$ [15]. In a previous work, we have studied the structure properties of small quantities zinc ions substituted $\mathrm{CuFe}_{2} \mathrm{O}_{4}$, which revealed that the 
structural transformation for $\mathrm{Cu}_{0.95} \mathrm{Zn}_{0.05} \mathrm{Fe}_{2} \mathrm{O}_{4}$ from tetragonal to cubic space group occurs in the temperature range from $\sim 50^{\circ} \mathrm{C}$ to $\sim 200^{\circ} \mathrm{C}[16]$.

Research in the framework of Hasylab (Desy, Hamburg) project made possible the investigations on the low temperature phase transition for both samples using the high-resolution $\mathrm{X}$ ray diffractometer. Figure 3 shows the (113), (311) and (222) reflections for $\mathrm{CuFe}_{2} \mathrm{O}_{4}$, from the synchrotron X-ray powder diffraction data, recorded in the temperature range from $300 \mathrm{~K}$ to $15 \mathrm{~K}$. There is no phase transition effect with decreasing temperature, and the sample remains tetragonal in the whole temperature range. The volume parameter, $V$, of the tetragonal phase $\left(F 4_{1} d d m\right)$ decreases with temperature from 589.69(0.11) $\AA^{3}$ to 588,04(0.11) $\AA^{3}$.

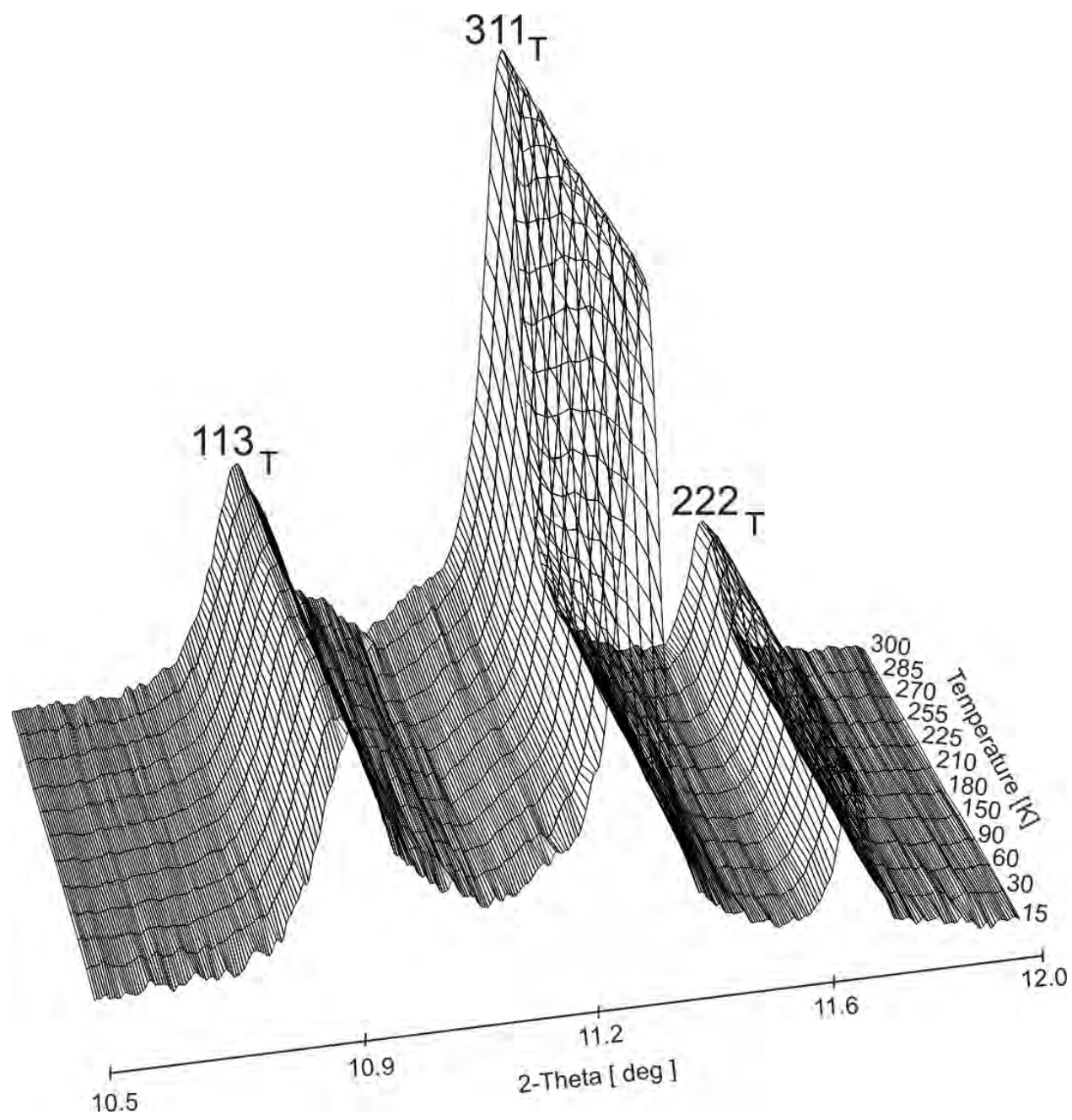

Figure 3. Low temperature evolution of the $\mathrm{X}$-ray powder diffraction patterns for $\mathrm{CuFe}_{2} \mathrm{O}_{4}$. 
Low temperature X-ray diffraction patterns for the $\mathrm{Cu}_{0.9} \mathrm{Zn}_{0.1} \mathrm{Fe}_{2} \mathrm{O}_{4}$ oxide are shown in figure 4. With decreasing temperature the formation of the tetragonal polymorph was indicated at about $255 \mathrm{~K}$. The splitting of the lines and their intensity reveal clearly the tetragonal structure (space group $F 4_{1} d d m$ ). The coexistence of two phases in a whole measurements range of temperature may be observed.

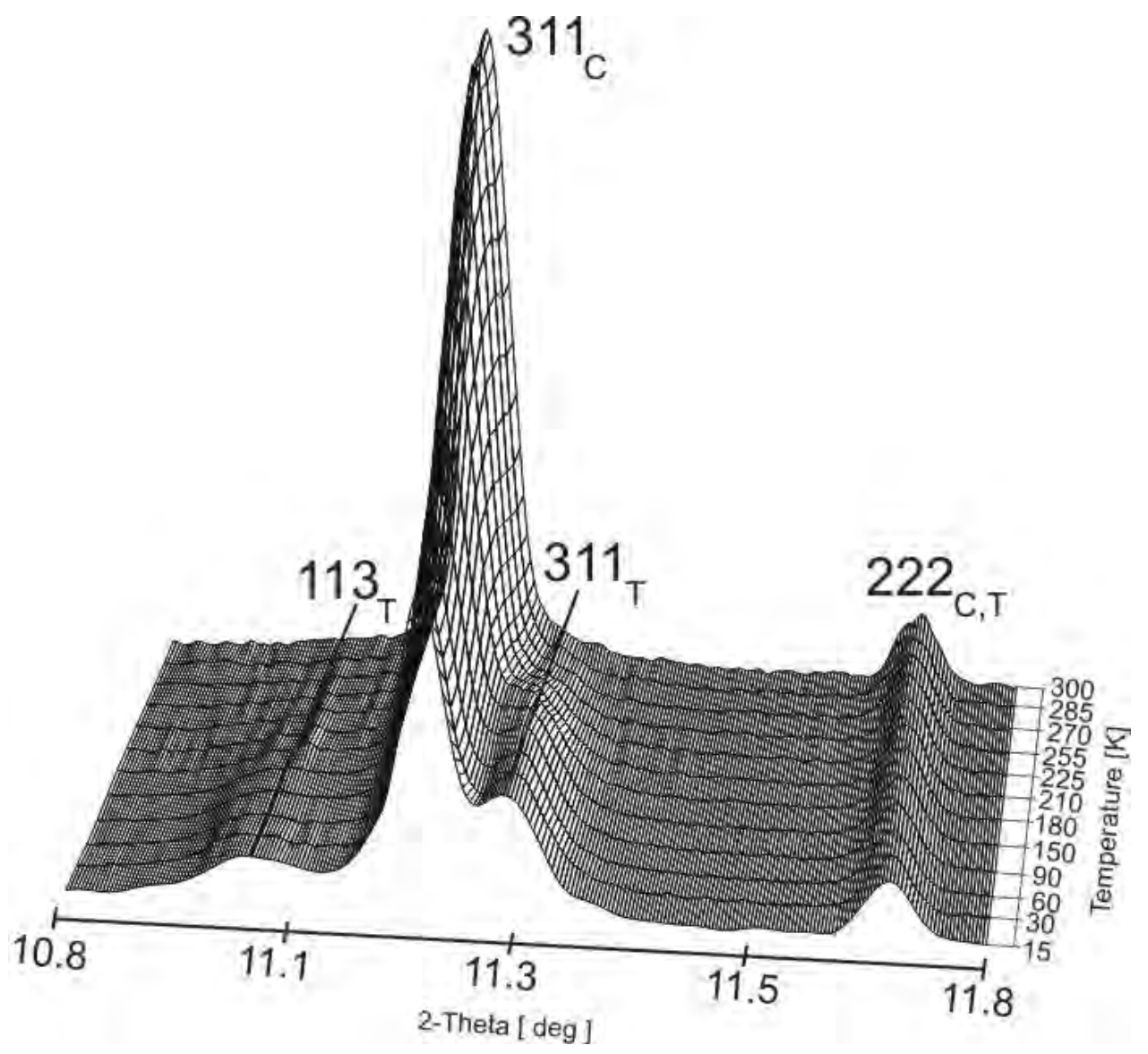

Figure 4. Low temperature evolution of the $\mathrm{X}$-ray powder diffraction patterns for $\mathrm{Cu}_{0.9} \mathrm{Zn}_{0.1} \mathrm{Fe}_{2} \mathrm{O}_{4}$.

\section{Concluding remarks}

The $\mathrm{CuFe}_{2} \mathrm{O}_{4}$ and $\mathrm{Cu}_{0.9} \mathrm{Zn}_{0.1} \mathrm{Fe}_{2} \mathrm{O}_{4}$ were synthesized by a combustion method using citratenitrate precursors. The formation of the tetragonal $\mathrm{CuFe}_{2} \mathrm{O}_{4}$, and the cubic $\mathrm{Cu}_{0.9} \mathrm{Zn}_{0.1} \mathrm{Fe}_{2} \mathrm{O}_{4}$ phases were confirmed by X-ray diffraction studies. Substitution with $\mathrm{Zn}^{2+}$ ions reduces the total concentration of $\mathrm{Cu}^{2+}$, suppressing the Jahn-Teller effect, and stabilizes the cubic structure. The substitution of divalent zinc ions in $\mathrm{Cu}_{1-\mathrm{x}} \mathrm{Zn}_{\mathrm{x}} \mathrm{Fe}_{2} \mathrm{O}_{4}$ spinel oxides increases the lat- 
tice parameters of the system. No phase transition has been observed in the $\mathrm{CuFe}_{2} \mathrm{O}_{4}$ spinel below room temperature. The sample remains tetragonal when cooled in the range $300 \mathrm{~K}-$ $15 \mathrm{~K}$. On the other hand the compound with small quantities of $\mathrm{Zn}^{2+}$ ions undergoes at $250 \mathrm{~K}$ temperature region a structural transformation from cubic $(F d 3 m)$ to tetragonal $\left(F 4_{1} d d m\right)$ lattice, with the coexistence of both phases down to $15 \mathrm{~K}$. Further investigation on the structure properties of the $\mathrm{Cu}_{1-\mathrm{x}} \mathrm{Zn}_{\mathrm{x}} \mathrm{Fe}_{2} \mathrm{O}_{4}$ system are indispensable.

\section{References}

1. Watanabe, S.C., Bamne, S.P. \& Tangsali, S.P., 2007, Mater. Chem. Phys., 103, 323.

2. Hancare, P.P., Patil, R.P., Sankpal, U.B., Jadhav, S.D., Lokhande P.D., Jadhav K.M. \& Sasikala, R., 2009, J. Solid State Chem., 182, 3217.

3. Rana, M.U., Islam, M. \& Abbas, T., 2000, Mater. Chem. Phys., 65, 345.

4. Argentina, G.M. \& Baba, P.D., 1974, IEEE Trans. Microwave Theory Tech. MTT, 22, 652.

5. Sun, S., Murray, C.B., Weller, D., Follks, L. \& Morse, A., 2000, Science, 287, 1989.

6. Prince, E. \& Treuting, R.G., 1956, Acta Cryst., 9, 1025.

7. Tang, X.X., Manthiram, A. \& Goodenough, J.B., 1989, J. Solid State Chem., 79, 250.

8. Knapp, M., Baehtz, C., Ehrenberg, H. \& Fues,s H., 2004, J. Synchrotron Rad., 11, 328.

9. Knapp, M., Joco, V., Baehtz, C., Brecht, H.H., Berghaeuser, A., Ehrenberg, H., Seggern, H. \& Fuess, H., 2004, Nucl. Instr. Meth. Phys. Res. A, 521, 565.

10. Rodriguez-Carvajal, J., 2001, Newslett. IUCr Commission Powder Diff., 26, 12.

11. Holland, T.J.B. \& Redfern, S.A.D., 1997, J. Appl. Crystallogr., 30, 84.

12. Holland, T.J.B. \& Redfern, S.A.D., 1997, Mineral. Mag., 61, 65.

13. Roisnel, T. \& Rodriguez-Carvajal J., 2000, Proceedings of the Seventh European Powder Diffraction Conference (EPDIC 7), p.118.

14. Shannon, R.D. \& Prewitt, C.T., 1970, Acta Crystallogr., B26, 1076.

15. Darul, J., 2009, Z. Kristallogr. Suppl., 30, 335.

16. Darul, J. \& Nowicki, W., 2009, Rad. Phys.Chem., 78, S109.

Acknowledgements. This research is partially supported by the Ministry of Science and Higher Education (Poland), grant No. NN204330537.

The research leading to these results has received funding from the European Community's Seventh Framework Programme (FP7/2007-2013) under grant agreement nº 226716. 